\title{
Urine fluorescence in antifreeze poisoning
}

\author{
Salem A Salem, ${ }^{1}$ Sidhanta Gurung, ${ }^{2,3}$ Abhishek Maiti ${ }^{2,3}$
}

'Department of Internal Medicine, Lyndon B. Johnson General Hospital, Houston, Texas, USA

${ }^{2}$ Department of Internal Medicine, University of Texas Health Science Center at Houston, Houston, Texas, USA ${ }^{3}$ Division of Cancer Medicine, University of Texas MD Anderson Cancer Center, Houston, Texas, USA

\section{Correspondence to} Dr Abhishek Maiti, abhishek. maiti@uth.tmc.edu

Accepted 15 June 2017

\section{DESCRIPTION}

A 48-year-old man with diabetes mellitus and alcohol abuse presented to the emergency room (ER) with altered mental status, vomiting and abdominal pain. On examination, he was confused and uncooperative with a blood pressure of $70 / 40 \mathrm{~mm} \mathrm{Hg}$, heart rate of 66 beats/min, respiratory rate of 30 breaths/min and oxygen saturation of $95 \%$ on room air. Initial venous blood gas showed a $6.57 \mathrm{pH}$ and $\mathrm{PaCO}_{2}$ of $33 \mathrm{~mm} \mathrm{Hg}$. Laboratory investigation showed serum bicarbonate of $5 \mathrm{mEq} / \mathrm{L}$, serum creatinine of $2.5 \mathrm{mg} / \mathrm{dL}$ (baseline creatinine $1.1 \mathrm{mg} / \mathrm{dL}$ ), blood sugar of $200 \mathrm{mg} / \mathrm{dL}$, anion gap of $29 \mathrm{mmol} / \mathrm{L}$, delta ratio of 0.9 , lactic acid of $21 \mathrm{mmol} / \mathrm{L}$, a serum osmolality of $360 \mathrm{mOsm} / \mathrm{kg}$ and an osmolar gap of $44 \mathrm{mOsm}$; blood alcohol level was $0.053 \mathrm{~g} / \mathrm{dL}$, and urine was negative for ketones. Bedside examination of a urine samples (figure 1) and mouth under Wood's lamp showed blue-green fluorescence, which raised suspicion of ethylene glycol poisoning secondary to antifreeze ingestion. Serum level of ethylene glycol was found to be $133 \mathrm{mg} / \mathrm{dL}$. Urinalysis showed cigar and dumbbell-shaped calcium oxalate crystals.

The toxic metabolites of ethylene glycol are glycolic acid and oxalic acid. Glycolic acid causes a high anion gap metabolic acidosis due to inhibition of cellular respiration. ${ }^{1}$ Glycolic acid can also cause false elevation of lactate on blood gas measurements. ${ }^{2}$ Most antifreeze preparations have added fluorescein to help detect radiator leaks, and fluorescence of the urine sample under ultraviolet light will be evident. ${ }^{3}$ Hence, urine fluorescence can be a helpful aid in bedside diagnosis of ethylene glycol poisoning. However, it should be used with caution, and results should be interpreted in the clinical context. Sodium fluorescein fluorescence is dependent on urine $\mathrm{pH}<4.5$ and has a half-life of just

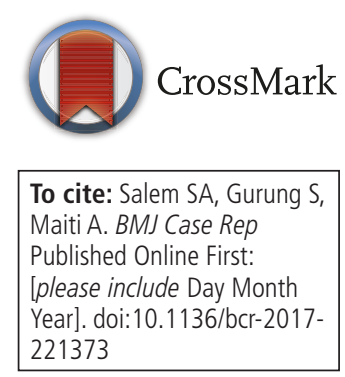

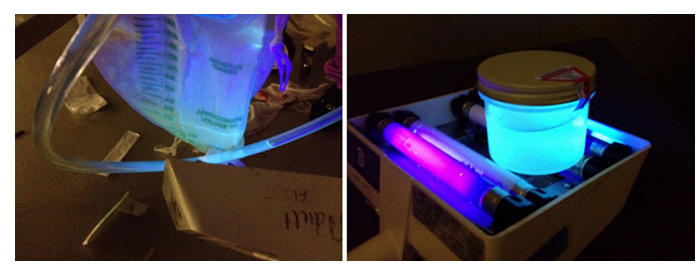

Figure 1 Urine sample showing blue-green fluorescence under ultraviolet light. over 4 hours allowing for potential false-negative results. ${ }^{1}$ Food products, toxins and drugs can cause urine fluorescence, or urine bags may have native fluorescence, leading to false-positive results. ${ }^{13}$ Urine in the paediatric population may show fluorescence in the absence of antifreeze. ${ }^{4}$

This patient received fomepizole, sodium bicarbonate, thiamine, intubation for airway protection and emergent haemodialysis. The antifreeze ingestion was thought to be accidental. He made an excellent recovery and was discharged home after 4 days.

\section{Learning points}

- Ethylene glycol is an active ingredient in commercial antifreeze, and ethylene glycol poisoning classically causes high anion gap metabolic acidosis with high osmolar gap.

- Most antifreeze preparations have added fluorescein to help detect radiator leaks and show a green-blue fluorescence under ultraviolet light.

- When antifreeze ingestion is suspected in the emergency room, Wood's lamp examination of the patient's mouth, vomitus, urine or clothing can aid in rapid diagnosis. However, this examination should be used with caution given potential for false-negative and falsepositive results.

Contributors SAS provided care for the patient and edited the manuscript for important intellectual content. SG and AM collected the data and drafted the manuscript. All authors approved the final version.

Competing interests None declared.

Patient consent Obtained.

Provenance and peer review Not commissioned; externally peer reviewed.

(c) BMJ Publishing Group Ltd (unless otherwise stated in the text of the article) 2017. All rights reserved. No commercial use is permitted unless otherwise expressly granted.

\section{REFERENCES}

1 Kraut JA, Kurtz I. Toxic alcohol ingestions: clinical features, diagnosis, and management. Clin J Am Soc Nephrol 2008;3:208-25.

2 Maiti A, Das A. A man with altered mental status and metabolic acidosis. BMJ 2016;353:i2338.

3 McStay CM, Gordon PE. Urine fluorescence in ethylene glycol poisoning. N Engl J Med 2007;356:611.

4 Casavant MJ, Shah MN, Battels R. Does fluorescent urine indicate antifreeze ingestion by children? Pediatrics 2001;107:113-4. 
Copyright 2017 BMJ Publishing Group. All rights reserved. For permission to reuse any of this content visit http://group.bmj.com/group/rights-licensing/permissions.

BMJ Case Report Fellows may re-use this article for personal use and teaching without any further permission.

Become a Fellow of BMJ Case Reports today and you can:

- Submit as many cases as you like

- Enjoy fast sympathetic peer review and rapid publication of accepted articles

Access all the published articles

- Re-use any of the published material for personal use and teaching without further permission

For information on Institutional Fellowships contact consortiasales@bmjgroup.com

Visit casereports.bmj.com for more articles like this and to become a Fellow 